\title{
覆い構造体空間のイメージとそ CG SURVEY OF IMAGERIES AND THE の空間構成要因の CG 実験調 ELEMENTS ORGANIZATIONS OF 査 COVERING ARCHITECTURAL STRUCTURES
}

神津康行 一 $* 1$ 鈴木信宏 $-* 2$

キーワード

覆い構造体, 空間構成, CG モテル, イメーシ構造, 空間秩序

Keywords

Covering architectural structures, Elements organization, CG model, Imagery structure, Spatial order

\section{$1 \%$}

多くの建築作品の中で、ヴォーレン高等学校、聖ベネディクト教会な ど、これら実例においては、その特徽として様々な単位の粠造体をあ る秩序をもって規則的に悓置し、さらにそれらで内部空間全体を覆う ことによって建筑内部空間全体の魅力を強く演出しているように感じ た。そこで本研究ではこのような構造体を「覆い構造体」と定義し、こ れらある秩序をもとに規則的に配置された内部空間覆い構造体に着目 することにより、その魅力をもたらすイメージと要因を捉えることが できるのではないかと考えた。

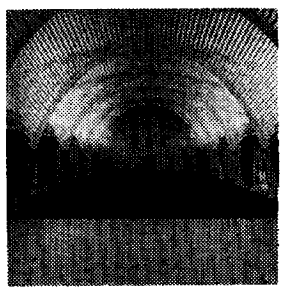

Wohlen High School

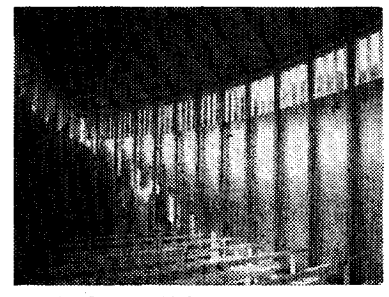

辢ベネディクト数会

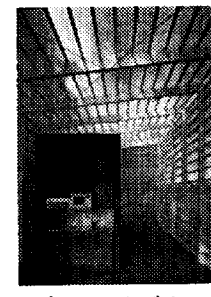

レジャースタジオ

\section{(1) 研究の视点及び目的と方法}

䅇い構造体空間を分析するにあた

り、5代表実例を選定した。次に写

真観察を主とした 5 実例のイメ一 ジと要因を予想し、素材と太陽光 の動きを除外した要素に着目した。 そして再度検討を行った結果、覆 い構造体空間のイメージを左右する と思われる空間構成要秦を視点と して設定した（图1と表2）。 イメージとしては空間秩序イメー ジ・雰囲気イメージ・運動イメージ・

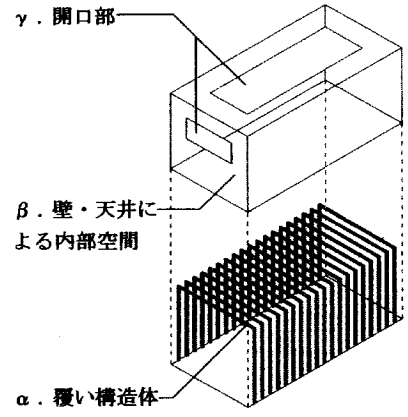

図 1 本研究で着目した 3 要素
詊価イメージに着目した。以上を視点に、変形モデルCGを作成し、ア ンケートを行い、目的 (1) CG 実験により 5 実例のイメージとその要 因を空間要素とその要素構成によって捉えること。目的 (2) 写真観察 を主とした 5 実例のイメージと要因の予想と CG 実験によるイメージ と空間構成要因の調査を比較することにより、CG実験調査の成果と課
Yasuyuki KOZU —-*1 Nobuhiro SUZUKI - $* 2$

We arranged imageries and elements organizations of covering architectural structures by observation of 5 typical spaces by means of book photographs. And we set several transformed CG models for each of the 5 spaces changing form and placement of covering structure, surface, and opening. We operated questionnairs to 29 architectural students showing the model photos. We clarified the imagery structures : relations between 4 representative spatial order imageries and form and placement of organization elements.

題を捉えることを目的とした。実験では、素材と太陽光の動きを除外 していることもあって、この報告では雾囲気と運動イメージは省略 し、空間秩序イメージの構成要因についてだけの考察を報告する。

\section{(2) 研究の位贯付け}

軸組み架構の類型化に関する北島たちの研究 ${ }^{1}$ (1999) はあるが、軸組 覆い構造体のイメージと要因の研究は、最近は見当たらない。鈴木・ 明田川の徳利屋の研究 ${ }^{3}$ (1991) が初期の研究であるが、そこでは被験 者が実際の空間を訪れて、インタビューに答えたのに対し、この研究 は要素限定のためにCG写真を見せて、アンケートをとった。また、 CGアニメーションを手法とする明暗空間配置の研究としては伊知地 たちの研究4（2001）があげられる。

\section{2 研究手闻}

視点の設定の後、次の手順でこの研究を行った。

1. 研究対象の設定 (表 1 参照) $\rightarrow 2$. 写真観察を主とした 5 害例の イメージと要因の予想 $\rightarrow$ 3. 空間構成要因の設定 $\rightarrow$ 4. 変形モ デルの設定 $\rightarrow$ 5. イメージの選定 $\rightarrow$ 6. 変形モデルごとのCG実 験アンケート $\rightarrow$ 7.CG実験による覆い構造体空間のイメージ構造 分析 $\rightarrow$ 8. 実例写真と C Gによる方法の比較考察

(1) 研究対象の設定（表 1 参照）

（1）覆い構造体が明確に見え、(2) 空間が魅力的で、(3) その形㸃や 配置等の着目要素の偏りの少ないと考えた 5 実例を研究対象とした。

表 1 対象実例一筧

\begin{tabular}{|c|c|c|c|c|}
\hline 帮晒o & 名称 & 設徫者 & 嵱工 & 舧 \\
\hline Na 1 & アムステルタム & HP.ペルデー & 1903年 & アムステルタム オランタ \\
\hline No 2 & 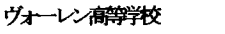 & サンテイアコ・カラトラ゚ & 1988年 & ウォーレッ、スス \\
\hline Na. 3 & 聖“䄁ィク侩 & ピーター・ストー & 1989年 & スイス スンヴィッツ \\
\hline Na 4 & レジャ・不沂 & タループ・モカーク & 1998年 & フィンランド、エクスポ \\
\hline & & & 19856 & \\
\hline
\end{tabular}

（2）写真锚察を主とした 5 実例のイメージと要因の予澌

実例写真锤察、インタビュー、文献調查により、5実例のイメージと 要因を予想した ${ }^{2}$ 。その際、素材と太陽光の動きも考虑し要因を制限 せず、多視点から予想を行った。

\footnotetext{
*1 Tansei Company, M. Eng.

*2 Prof., Science University of Tokyo, Dr. Eng.
} 


\section{（3）空间粠成要因の設定}

$\lceil\boldsymbol{\alpha}$. 覆い構造体」について「e.トラスを設置する」などの「 $\boldsymbol{\alpha}-1$. 形態」 $(\mathrm{a} \sim \mathrm{h}) 、 「 \mathrm{i}$. 構造体同士のピッチが大」などの「 $\alpha-2$. 配置」 $(\mathrm{i} \sim \mathrm{m}) 、 「 \beta$. 壁・天井による内部空間」について「o. 木の葉形にす る」などの「 $\beta-1$. 平面形態」 $(\mathrm{n} \sim 0) 、 「 \mathrm{p}$. 切妻形にする」などの 「 $\beta$-2. 断面形態」 $(\mathrm{p} \sim \mathrm{q}) 、 「 \gamma$. 開口部」について「s. トップライ 卜」などの「 $y-1$. 眠置」 $(r \sim t) 、 「 v$. 棟部分を残す」などの「y-

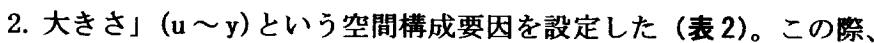
「i．ピッチが大」などを基準として、覆い樓造体空間基本要因を設定 した (表 3)。

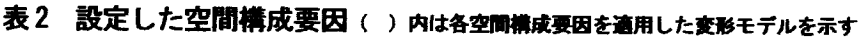

\begin{tabular}{|c|c|c|c|}
\hline \multicolumn{2}{|c|}{ 着目要素 } & \multicolumn{2}{|c|}{ 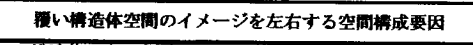 } \\
\hline \multirow{13}{*}{ 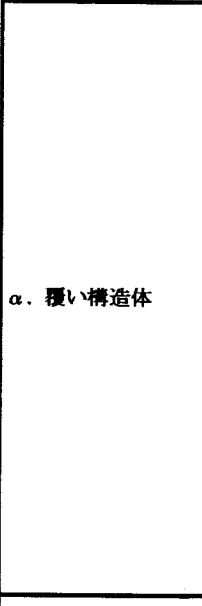 } & \multirow{8}{*}{$\alpha-1$. 形想 } & 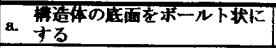 & (変形モデルー01, 08, 19) \\
\hline & & 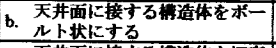 & 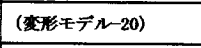 \\
\hline & & 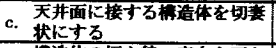 & （雪形モデルー02） \\
\hline & & 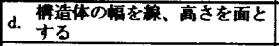 & (讋形モデル-07, 18) \\
\hline & & e. トラスを設温ナる & （索形モデルー03） \\
\hline & & 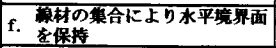 & (霍斯モデル-09) \\
\hline & & 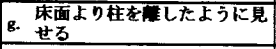 & (䴬形モデルー04) \\
\hline & & h. スバンを広げる & （変形モデルー07） \\
\hline & \multirow{5}{*}{$\alpha-2$. 撸 } & I. 梏造体同士のピッチが大 & (恋形モデルー01，14） \\
\hline & & 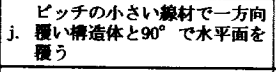 & (変榇モデルー15) \\
\hline & & 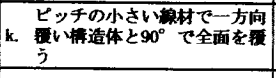 & (㚆形モデル-16) \\
\hline & & 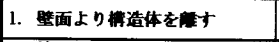 & (数モデル11) \\
\hline & & 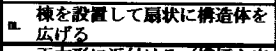 & (教形モデルー12) \\
\hline \multirow{4}{*}{$\beta$. 䢃・天井によるる } & \multirow{2}{*}{$\beta-1$. 平面形慗 } & 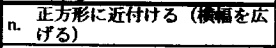 & (麥形モデルー07) \\
\hline & & 。. 木の藮形にする & (霆形モデルー12) \\
\hline & \multirow{2}{*}{ B-2. 断面形数 } & p. 切表形にする & （変形モデルー02） \\
\hline & & q. ボールト形にする & (変形モデル-09) \\
\hline \multirow{8}{*}{ y. 闌口部 } & \multirow{3}{*}{$y-1$. 酉置 } & r. 㪙・不井全面 & (倊形モデル-17) \\
\hline & & s. トップライト & (交形モデルー05) \\
\hline & & t. ハイサイドライト & (変形モデルー06, 10, 13) \\
\hline & \multirow{5}{*}{$\gamma-2$. 大きさ } & u. 壁・天井全面 & (真形モテルー17) \\
\hline & & v. 林部分を茷与 & (表形モテルー05) \\
\hline & & 5. 周開壁 & (妻形モデルー13) \\
\hline & & x. 墥两サイド全面 & (旁形モデル-10) \\
\hline & & y. 妻面仩小さな姖形 & （教形モデルー06） \\
\hline
\end{tabular}

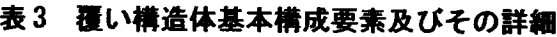

\begin{tabular}{|c|c|c|c|}
\hline \multicolumn{2}{|c|}{ 着目要素 } & $\begin{array}{c}\text { 覆 構造体 } \\
\text { 基構成垔素 }\end{array}$ & 注 \\
\hline \multirow{3}{*}{ a. 覆 構造体 } & $\alpha-1$. 形態 & (1) 篗造体の太さ & 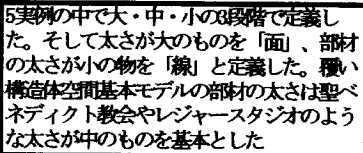 \\
\hline & \multirow[t]{2}{*}{$\alpha-2$ 配置 } & 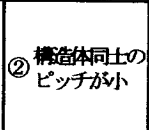 & 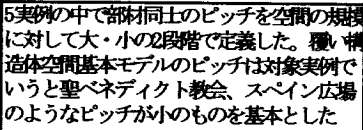 \\
\hline & & $\begin{array}{l}\text { 整面 天井面 } \\
\text { (3) と摩造体力接 } \\
\text { している }\end{array}$ & r \\
\hline \multirow{2}{*}{$\beta$. 壁・天井によ } & B-1. 平面形悲 & (4)矩形 & \\
\hline & 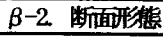 & (5) 矩形 & \\
\hline \multirow{2}{*}{ y. 開口部 } & $y-1 . \quad$ 配置 & (6)なL & \\
\hline & $y-2$ 大きさ & (7)なし & \\
\hline
\end{tabular}

\section{（4）变形モデルの設定}

設定した空間構成要因を順次、基本モデルに加えて各実例へと近付け ていくことにより変形モデルを設定した（CG参照)。また比較のため に覆い構造体空間基本モデルと覆い構造体を有さない直方体空間モデ ルを設定した。

(5) イメージの選定 (表 4)

写真観察を主とした 5 実例のイメージと要因の予想と既往研究から 「連続感があるー不連続な」といった空間秩序イメージ 17 対、「柔ら かさを感じる一堅さを感じる」といった空間雲囲気イメージ9対、「歩 き回りたいーじっとしていたい」といった運動イメージ2対、「好きー 嫌いといった評価イメージ 5 対の計 33 のイメージを選定した。

表 4 選定した 33 イメージ

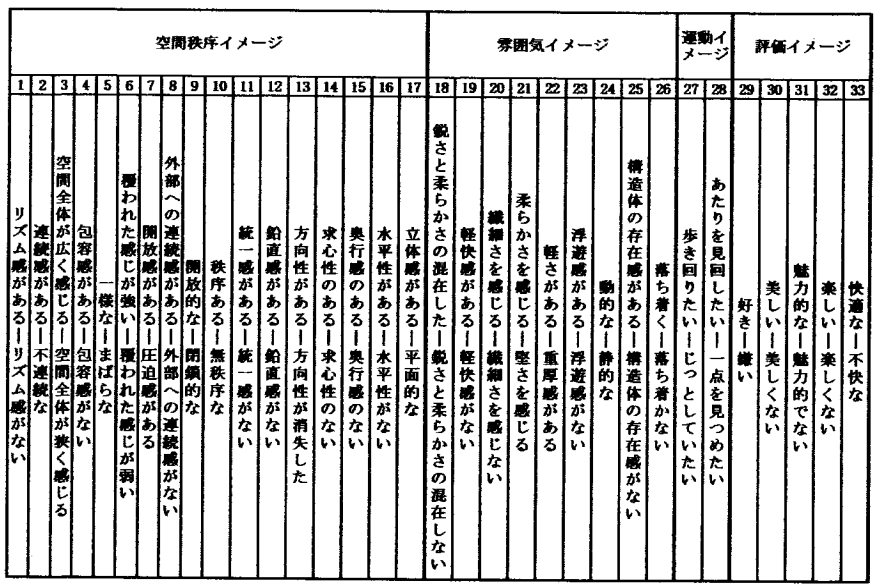

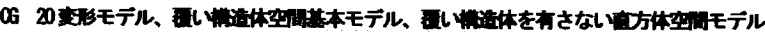

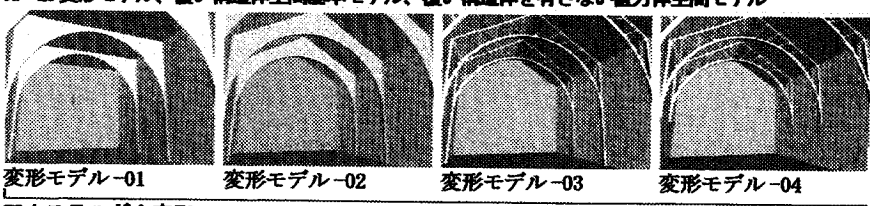

アムステルダム京形 $\Rightarrow$
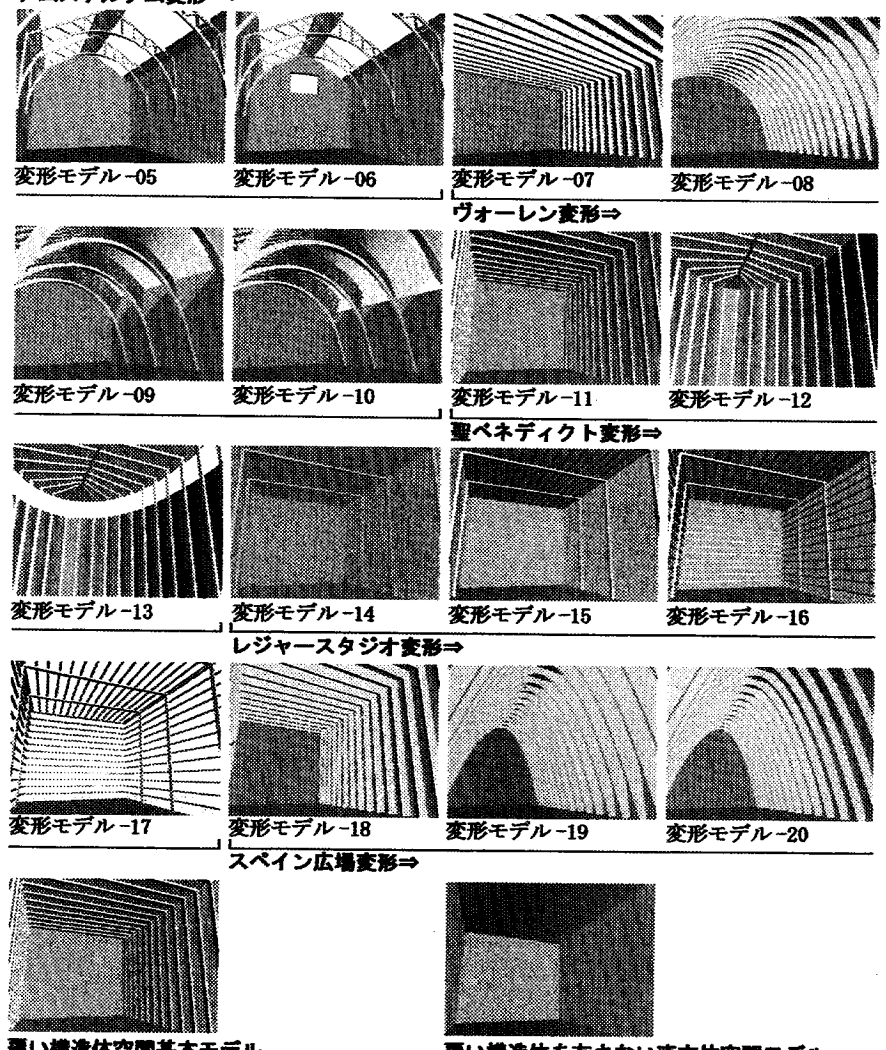

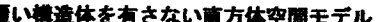


(6) 変形モテルごとの CG 实験アンケート

アンケートの所用時間は 1 人あたり約 1 時間であり、各々に口答で研 究内容を充分説明し、CGモデル写真を貼った A3 用紙 16 枚を配付する ことにより建築学科学生 29 人に対して行った。そして空間全体から 感じるイメージを 7 段階で評価させた。

(7) 实例写其とCGによる方法の比较考察

\section{CG 实卧による到い得造体空同のイメージ得造の分析}

（1）イメージ因子軸の萑得

アンクート結果を因子分析した結果 17 対の空間秩序イメージを $4 つ$ のイメージ因子軸に代表させることができた。

因子I軸:開放 $\Leftrightarrow$ 閉鎖

開放：「空間全体が広く感しる」「開放的な」「開放感がある」「外部への連続 感がある」「覆われた感じが弱い

用鎖 :「空間全体が狭く感じる」「閣鎖的な」「圧迫感がある」「外部への連繶感 がない「覆われた感じが強い」

因子II軸：リズム↔単調

リスム：「奥行感のある」「方向性があ」「連続感がある」「リズム感がある」 「立体感がある」

単娚:「奧行感のない」方向性が消失した」「不連繶な」「リズム感がない」「平 面的な」

因子III軸：統一美異

珫一：「統一感がある」「秩序ある」「一梯」

差異 :「統一感がない「「無秩序な」「まばらな」

因子IV軸：包容自散

包容：「水平性がない「包容感がある」「求心性のある」「鉛直感がない」

発散 :「水平性がある」「包容感がない「求心性のない「鉛直感がある」

（2）因子得点による考察

それぞれの変形モデルにおける各イメージ因子の因子得点を求めた (表4参照)。そしてそれぞれの空間構成要因があるモデルに加えられ たときの各因子の変動を求めた。さらにその結果と相関分析を参照し ながら、各空間構成要因が空間に与える因子の強さを捉えた（表 5 参 照)。

表 5 各变形モテルのイメージ因子に対する因子得点

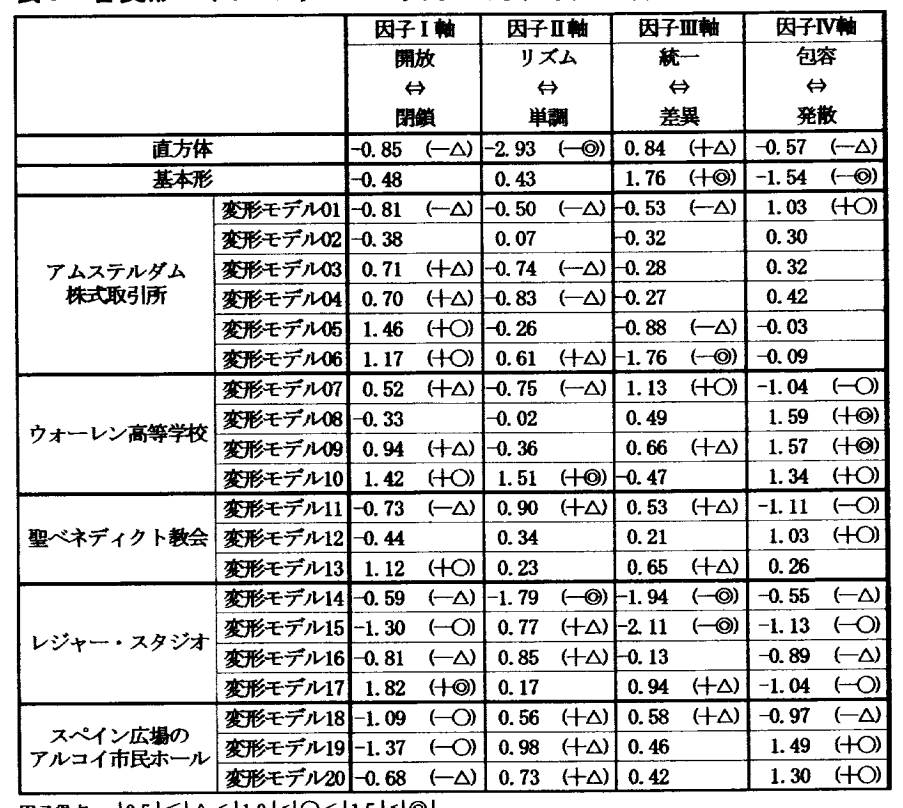

因子得点 $|0.5| \leqq|\Delta<| 10|\leqq| O<|15| \leqq|0|$

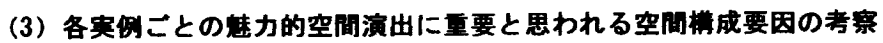
相関関保分析では「開放」「リズム」イメージ因子が特に「好き」と いったポジティブな評価イメージ群と相関が高かった。また「包容」 イメージ因子も高くはないがこれら評価イメージと相関があった。 「統一・差異」イメージ因子は評価イメージと相関がなかった。この 結果をもとに、開放」「リズム」「包容」イメージ因子に着目してそ れぞれの実例における魅力的空間演出に重要と思われる空間構成要因 の考察を行った。

\section{1）アムステルダム株式取引所}

変形モデル-06の因子得点では強い開放と リズムの空間であった。開放は「e.トラス を設置する」ことにより強く空間に与えら れていた。アムステルダム株式取引所の魅 力を強く演出しているといえそうである。

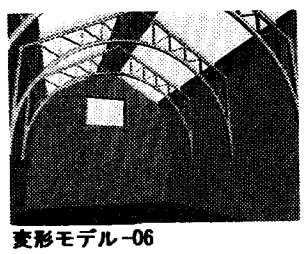
また「a. 構造体の底面をボールト状にする」による開放と「c. 天井 面に接する構造体を切妻状にする」による包容という異なるイメージ 因子が構造体の形態を操作することにより一つの構造体の中に介在し ていると同時に、リズム因子を共有することによりリズムを強めてい た。さらに開放とリズムは「s. トップライト + u. 棟部分を残寸」に より強められ、リズムは「 $\mathrm{t}$. ハイサイドライト + y. 妻面に小さな 矩形の開口」により強められていた。

2) ウォーレン高等学校

変形モデル-10の因子得点では「非常に強 いリズム」、「強い開放」「強い包容」の空 間であった。このリズムは「a. 構造体の底 面をボールト状にする（床面より曲率がゆ るいアールの構造体)」と「t. ハイサイド

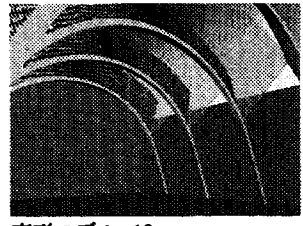

変形モデル -10 ライトにする $+\mathrm{x}$. 壁両サイド全面」によるものであった。開放は「h. スパンを広げる」、「n. 正方形に近付ける（横幅を広げる）、「f f. 線材 表 6 实俔こととの空間權成要因が空間に与えるイメージ因子の強さ

\begin{tabular}{|c|c|c|c|c|c|c|c|c|c|}
\hline & \multicolumn{8}{|c|}{ 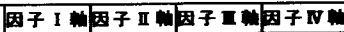 } \\
\hline & & 虫 & 翼 & $\frac{1}{x}$ & $\frac{1}{10}$ & 萑 & 基 & 包 & 魚 \\
\hline 吉方体 & 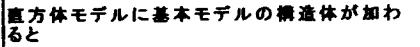 & & & $\Delta$ & & & $\mathrm{O}$ & $\Delta$ & \\
\hline \multicolumn{10}{|c|}{ アムステルタム镂式取引章 } \\
\hline モデル01 & 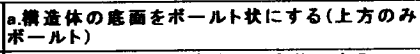 & & $\Delta$ & $\Delta$ & & & & $\Delta$ & \\
\hline モデル02 & 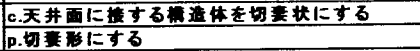 & $\Delta$ & & $\Delta$ & & & & & $\Delta$ \\
\hline Еデル03 & 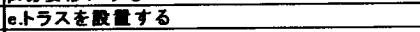 & $\mathrm{O}$ & & & $\Delta$ & & & & \\
\hline モデル04 & 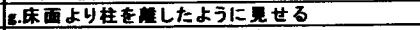 & & & & $\Delta$ & & & & \\
\hline モデル05 & 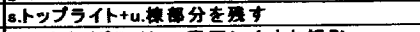 & $\Delta$ & & $\Delta$ & & & $\Delta$ & & $\Delta$ \\
\hline モデル06 & t.ハイサイドライト+y.集面に小さな炬的 & & & $\Delta$ & & & $\Delta$ & & \\
\hline \multicolumn{10}{|c|}{\begin{tabular}{|l|l|l} 
Wohlen High School \\
\end{tabular}} \\
\hline モデル07 & 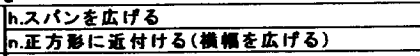 & 0 & & & 0 & $\Delta$ & & & \\
\hline モデル08 & 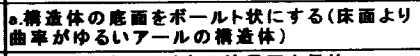 & & $\Delta$ & $\Delta$ & & & $\Delta$ & e & \\
\hline \multirow{2}{*}{ モデル09 } & 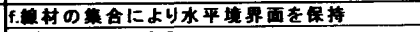 & $\mathrm{O}$ & & & $\Delta$ & & & & \\
\hline & q.ボールト訪にする & & & & & & & $\mathbf{0}$ & \\
\hline \multicolumn{8}{|c|}{ 量へネティクト数全 } & & \\
\hline モデル11 & 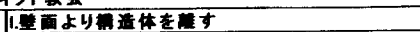 & & & $\Delta$ & & & 0 & $\Delta$ & \\
\hline モデル12 & 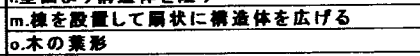 & & $\Delta$ & & & & $\Delta$ & 0 & \\
\hline 玉デル13 & t.ハイサイドライトにする+w.垶全雷 & $\mathrm{O}$ & & & & $\Delta$ & & & $\Delta$ \\
\hline \multicolumn{10}{|c|}{ レシャースタジオ } \\
\hline モデル14 & D.M体同士のピッチが大 & & & & - & & 0 & $\Delta$ & \\
\hline モデル15 & 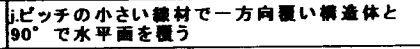 & & $\Delta$ & $\mathbf{0}$ & & & & & $\Delta$ \\
\hline モデル16 & 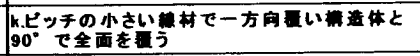 & $\Delta$ & & & & 0 & & & \\
\hline モデル17 & r.照·天井全面+u量·天井全面 & 0 & & & $\Delta$ & & & & \\
\hline \multicolumn{10}{|c|}{ スヘイン広媓アルコイ市民ホール } \\
\hline モデル18 & 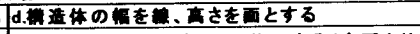 & $\Delta$ & & & & & 0 & & $\Delta$ \\
\hline モデル19 & 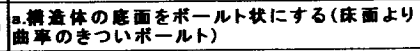 & & & $\Delta$ & & & & $\mathbf{0}$ & \\
\hline モデル20 & 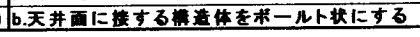 & $\Delta$ & & & & & & & \\
\hline
\end{tabular}


の集合により水平境界面を保持」「t. ハイサイドライトにする $+\mathrm{x}$. 壁両サイド全面」によるものであった。包容は「a. 構造体の底面を ボールト状にする（休面より曲率がゆるいアールの構造体）」、「q. ボールト形にする」によるものであった。強い開放と包容因子が存在 している例は他の4実例にはみられず、この空間の魅力の特徽といえ る。

\section{3）聖ベネディクト教会}

変形モデル-13の因子得点では開放が強い 空間であった。この開放は「t. ハイサイド ライトにする + w. 周囲壁」によるもので あった。また因子得点ではりズム、包容は 非常に弱かったが、リズムは「1. 壁面より

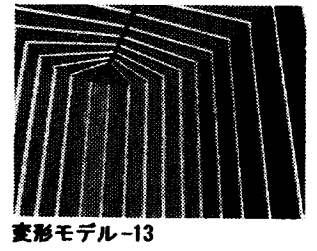
粠造体を麇す」と「t. ハイサイドライトにする＋w. 壁全面」によ るものであり、包容は「1. 壁面より構造体を僱す小、「m. 棟を設置し て扇状に構造体を広げる小「。. 木の葉形」によるものであった。その 中でも非常に目立たない「1. 壁面より構造体を䧹す」という空間構 成要因がリズムと包容を与えており魅力的空間演出のための重要な一 要因といえる。

4) レジャースタジオ

変形モデル -17 の因子得点では開放が非常 に強い空間であった。開放は「k.ピッチの 小さい線材で一方向覆い構造体と $90^{\circ}$ で全 面を覆う」、「r. 壁・天井全面 $+u$. 壁・天 井全面」によるものであった。中でも「k.

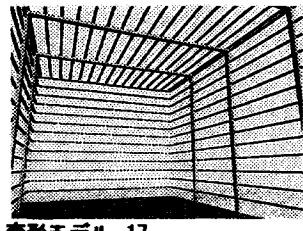
形モデルー17 ピッチの小さい線材で一方向覆い構造体と $90^{\circ}$ で全面を覆う」では 線材で空間全体を覆っているにも関わらず開放を得ていた。

5）スペイン広埥アルコイ市民ホール 変形モデル-20の因子得点では包容が強い 空間であった。この包容は「a. 構造体の底 面をボールト状にする（休面より曲率のき ついボールト)」によるものであった。また 因子得点では閉鎖を示していたが、「d. 構

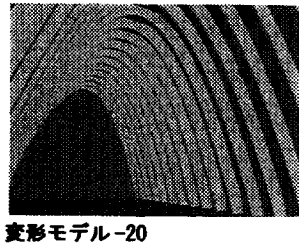
造体の幅を線、高さを面とする小、「b. 天井面に接する構造体をボ一 ルト状にする」によって閉鎖を弱めていた。

（4）全体を通して

ボールト形状による包容／矩形の壁と天井による内部空間の中にボー ルト形態の覆い構造体を設圈し、壁面との間に隙間を設けることによ る開放／壁面より覆い構造体の柱部分を離すことによるリズム、包容 ノサッシュのような線材により小さなピッチで空間全体を覆うことに よる開放／切妻形態による開放、リズム／線材の集合により一つの覆 い粠造体を形成 (トラスなど)することによる開放/スパンを広げる ことによる開放／部分的にハイサイドライト、トップライトを設置す ることによるリズム/トップライトによる開放／全面ハイサイドライ トによるリズム、開放／壁、天井全面開口による開放/といった空間 構成要因とイメージが鬼力的空間の要因になっていると思われる。

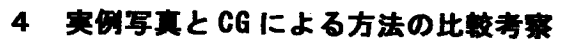

写真䚁察を主とした 5 実例のイメージと要因の予想と CG 実験による イメージと空間構成要因の調查を比較することにより、CG 実験の成 果と課題を捉えた。（1）レジャースタジオの文献 5 による調查では、
「透明な壁面が生ずる反射光は、空とそして周 囲の椹木と柔らかな関係性を取り結んでいる」、 「移ろいゆく日光、木の莱のそよぐ様子、風のさ さやきを強く感じさる」、「人の活動は太陽から 得る光と熱に応じて、四季の移ろうサイクルに 沿うものとなる」と記されていた。一方CG実験 では、太陽の時間的推移や反射光などを反映し ておらす、これら太陽光の動きに関する要因お よびイメージは捉えることができなかった。 （2）スペイン広場アルコイ市民ホールでは写真 による分析では、構造体の立面にアールをつけ ることにより「強い柔らかさ」、包容感」を与 えていると予想した。一方 CG 実験では、「a. 構 造体の底面をボールト状にする」により「リズ ム」、非常に強い包容」を空間に与えていた。 「4. 包容感がある」は包容因子の空間秩序イ メージであり、「21. 柔らかさを感じる」は包容 因子と相関の高い空間䨌囲気イメージであっ た。(3)これにより写真による分析とCGによる 分析が類似を示した。またCG実験では「リズム」 といった因子も捉えることができた。以上のよ うな考察を全ての実例に対し行った結果、全体 を通して写真観察を主とした 5 実例のイメージ と空間構成要因の予想とCGによる分析が類似し ており、設定した範囲内でイメージとその要因 を正確に把握することができ視点の有効性が確 認できた。

5 まとめ

写真䘽察を主として5実例のイメージと要因を予想し、素材と太陽光 の動きを除外して、覆い構造体空間のイメージを左右すると思われる 空間構成要因を設定して、これらを視点とした（表2)。それによって 22 の CG 変形モデルを設定し、アンケート実験を行った。それにより （1）5実例における空間の蜥力を強く演出しているイメージと空間楼 成要因を捉えることができた (3草)。(2) 写真钲察を主とした 5 実例 の空間秩序イメージと要因の予想と CG 実験によるイメージと空間構 成要因の関係を比較することにより、CG 実験の視点（表 2) の有効性 の確認した。(3)「素材イメージ・太陽光の動きによるイメージとそ の要因を未だ捉えていない」こと「CGと実際の建筑が与えるイメー ジの差を定量的に捉えていないこと」が課題として残る。これら、夷 祭の空間体験に近付けるための手段を探ることが今後の課題であると 考える。

注

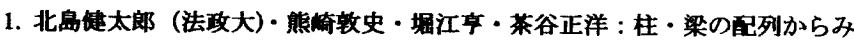

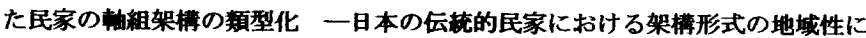
閣する研究 その 1 - E-1 分冊 pp.661、1999

2. 生沼玲・西本成志他 2 名 : 屋根裏棰造体の空問特徬とそれらのイメージの基

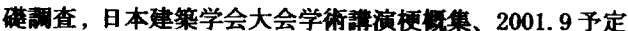

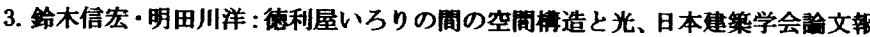
告集、421 号、1991.3、PP. 51-61

4. 伊知地雅博、鈴木信宏: 太陽光がつくる明喑建策空間の国置棈成類型のイメー

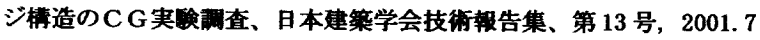
5. a+u 都市と建䉪 N $0.287 、$ p. 24、1994. 8

[2001年 4 月20日原稿受理 2001年 7 月27日採用決定］ 